\title{
経ロベラプロストナトリウム徐放性製剂（ケアロードロ $\mathrm{LA}$ 錠 $60 \mu \mathrm{g}$ ， ベラサス ${ }^{\circledR} \mathrm{LA}$ 錠 $60 \mu \mathrm{g}$ ）の特徵および臨床試験成績
}

車谷 元

要約：ケアロード ${ }^{\circledR} \mathrm{LA}$ 錠 $60 \mu \mathrm{g}$, ベラサス ${ }^{\circledR} \mathrm{LA}$ 錠 60 $\mu \mathrm{g}$ は，プロスタサイクリン $\left(\mathrm{PGI}_{2}\right)$ 誘導体であるべ ラプロストナトリウム（BPS）を有効成分とする経口 徐放性製剂であり，2007 年 10 月，「肺動脈性肺高血 圧症」(PAH) を効能・効果として承認を取得した。 BPS は東レ株式会社で創製された経口投与可能なプ ロスタサイクリン誘導体であり，その通常錠であるド

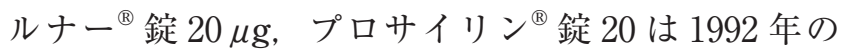
発売以降広く臨床応用されている. 本剤は, 有効血漿 中濃度の持続化, $\mathrm{C}_{\max }$ の抑制による服用回数の低減 とともに，1 日服用量の増加による治療効果の向上を 目的としたものである. 通常錠での知見や in vitroで の薬理作用から設定した目標血漿中濃度推移を達成す ることは, BPS の血漿中半減期が約 1 時間と短いた めに困難であったが, 独自のハイドロゲルマトリック ス製剂とすることでこれをクリアし，プロスタグラン ジン（PG）製剤としては世界に類のない経口徐放性 製剂を完成させた。本剂は, 肺動脈性肺高血圧症に対 して, 肺血管の選択的な拡張作用, 抗血小板作用, 血 管平滑筋細胞の増殖抑制作用などによってその病態を 改善する. 血小板凝集抑制作用が本剂投与後 12 時間 持続すること, 他の作用も血小板凝集抑制作用に類似 した濃度-作用関係を示すことから，1 日 2 回投与と した，健康成人における第 I 相試験で良好な徐放特性 が確認されたため,「原発性肺高血圧症および膠原病 に伴う肺高血圧症」の患者を対象とし，漸増法を用い た第 II 相試験によって, 本剂の有効性抢よび安全性 を評価した，その結果，主要評価項目である「6分間 歩行距離の差」に加え, 「平均肺動脈圧」や「全肺血 管抵抗」での効果が示された。本剤は, WHO 機能分 類 I 度, II 度の軽度患者からの投与が認められている
こと, CYP で代謝される薬物との併用によって互い に血漿中濃度に影響を及ぼす可能性が低いと推察され ることなど，使用にあたっての利便性が高いことから， 今日なお難治性疾患である肺動脈性肺高血圧症治療に, 新たな選択肢を提供するものとしてその将来が期待さ れる。

\section{1.はじめに}

ケアロード $\mathrm{LA}$ 錠 $60 \mu \mathrm{g}$, ベラサス ${ }^{\circledR} \mathrm{LA}$ 錠 $60 \mu \mathrm{g}$ （本 凰：ケアロードLA 錠, ベラサス LA 錠）は，プロス タサイクリン誘導体であるべラプロストナトリウム （BPS）（図 1）を有効成分とする経口徐放性製剤である. BPS は東レ株式会社で創製された経口投与可能なプ ロスタサイクリン誘導体であり $(1,2)$, 各種薬理試験 に执いて，プロスタサイクリンと同様の強力な血管拡 張作用，抗血小板作用，平滑筋細胞増殖抑制さらには 血管内皮細胞保護作用などを有することが確認されて いる(3). BPS の通常錠であるドルナー ${ }^{\circledR}$ 錠 $20 \mu \mathrm{g}$ （東 レ株式会社/アステラス製薬株式会社)，プロサイリ ン ${ }^{\circledR}$ 錠 20 (科研製薬株式会社)（BPS 通常錠）は，世 界初の経口投与可能なプロスタサイクリン製剤として,

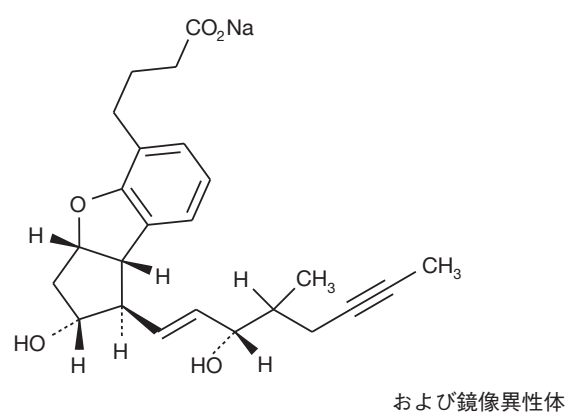

図 1 ベラプロストナトリウム (BPS) の構造式

キーワード：ケアロード LA 錠, ベラサス LA 錠, ベラプロストナトリウム，プロスタサイクリン，肺動脈性肺高血圧症 東レ株式会社 医薬研究所 ${ }^{1)}$, 医薬事業部 ${ }^{2)}$

(1) = 248-8555 神奈川県鎌倉市手広 6 丁目 10 番 1 号, ${ }^{2)}$ ７279-8555 千葉県浦安市美浜 1 丁目 8 番 1 号)

E-mail: Hajimu_Kurumatani@nts.toray.co.jp＼cjkstart原稿受領日：2008 年 8 月 3 日, 依頼原稿

Title: Pharmacological profiles and clinical effects of oral sustained release beraprost sodium (Careload ${ }^{\circledR} \mathrm{LA}$ Tablets $60 \mu \mathrm{g}$, Berasus ${ }^{\circledR}$ LA Tablets $60 \mu \mathrm{g}$ ). $\quad$ Author: Hajimu Kurumatani 
1992 年 1 月に「慢性動脈閉塞症に伴う潰瘍, 疼痛お よび冷感の改善」を適応症として承認されている，さ らに, 1999 年 9 月には, 「原発性肺高血圧症」の効能 追加が承認され，現在では広く臨床において使用され ている.

東レ株式会社では BPS 通常錠に引き続いて, 有効 血漿中濃度の持続化， $\mathrm{C}_{\text {max }}$ の抑制による服用回数の 低減とともに，1 日服用量の増加による治療効果の向 上を目的とした徐放性製剤の開発に取り組んだ。BPS は血漿中消失半減期が約 1 時間と短いために, その開 発は困難であったが，独自のハイドロゲルマトリック ス製剤とすることで，1 日 2 回投与で有効性を示す製 郕を開発し，2007 年 10 月，ケアロードLA錠（東レ 株式会社／アステラス製薬株式会社), ベラサス LA 錠（科研製薬株式会社）として,「肺動脈性肺高血圧症」 (PAH) を効能・効果に承認を取得した.

\section{2. プロスタサイクリンについて}

プロスタグランジン（PG）は, 生体内で産生され る生理活性物質であり, 各種刺激によって細胞膜リン 脂質より切り出されるアラキドン酸がその原料となる. 生理的に重要な $\mathrm{PG}$ には $\mathrm{PGD}_{2}, \mathrm{PGE}_{2}, \mathrm{PGF}_{2} \alpha, \mathrm{PGI}_{2}$ があり, それぞれに特徵的で多彩な生理活性を有して いる. $\mathrm{PGI}_{2}$ とほほ逆の生理活性を有するトロンボキ サン $\mathrm{A}_{2}$ も生体内でアラキドン酸から合成される (4).

このうち $\mathrm{PGI}_{2}$ はその構造的な特徴からプロスタサ イクリンともよばれ, 1976 年 Vane らによって発見さ れた(5)。主として血管内皮細胞で合成され, 細胞膜 表面上のプロスタサイクリン特異的なレセプター (IP) を介して作用を発現する。プロスタサイクリンレセプ ターは血小板, 血管平滑筋細胞, 血管内皮細胞, 単球 /マクロファージなどに分布しており，プロスタサイ クリンは, 主に細胞内の cAMPを上昇させることで,

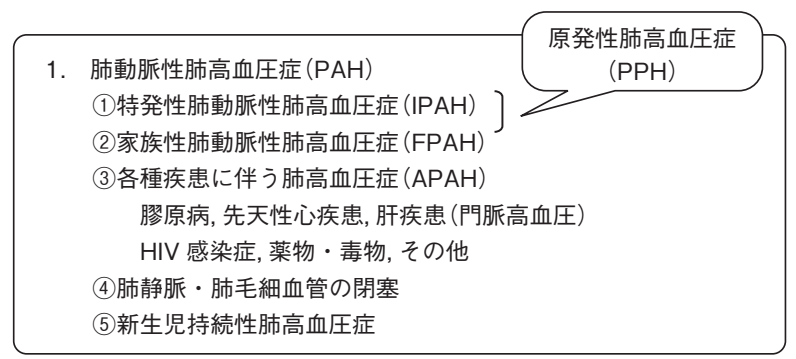

2. 左心性心疾患に伴う肺高血圧症

3. 肺疾患・低酸素血症に伴う肺高血圧症

4. 慢性血栓塞栓性疾患に伴う肺高血圧症

5. その他

サルコイドーシス, リンパ管腫症, 肺血管の圧迫

図 2 肺動脈性肺高血圧症の分類（ヴェニス分類） (文献 12 より改变)
それぞれの細胞に特徵的な機能を発現する(3).

プロスタサイクリンは生体内で多彩な作用を担って いる. 主な作用として, 血管拡張作用, 抗血小板作用, 平滑筋増殖抑制作用, 内皮細胞保護作用がある。ささ に近年では，血管内皮細胞からの NO 産生増加作用 (6)，血管内皮前駆細胞の骨髄から流血中や虚血障害 部位への動員作用 (7) なども明らかにされているが,

こうした作用は全て, 疾患に抒いて低下した組織血流 を回復させるという共通の方向性を有している。この ため, 発見当初から各種循環器疾患の薬物療法に新た な手段を提供するものとして期待された。 しかしなが らプロスタサイクリンは化学的に極めて不安定であり, その血漿中消失半隇期が非常に短いこと, 経口投与が 不可能であることなどの問題から, その使用はごく限 られた疾患にとどまっていた，BPSは，これらの欠 点を克服するために合成された, 経口投与可能なプロ スタサイクリン誘導体である $(1,2)$.

\section{3. 肺動脈性肺高血圧症とは}

肺高血圧症は，肺動脈圧が異常高值を示す疾患の総 称であり,このうち肺動脈性肺高血圧症は肺動脈に病 変の首座があるものをいう（図 2) $(8,12)$.

肺動脈性肺高血圧症のうち原発性肺高血圧症 $(\mathrm{PPH})$ は, 厚生労働省の定める特定疾患治療研究事業におけ る対象疾患（難病）に指定された希少疾患であり, 年 齢にかかわらず発症するが，若年層では女性に多く認 められ，その予後は極めて不良である. PPH の成因 は未だ不明であるが, 病変は主に毛細血管前の動脈に あり (前毛細血管性), 原因不明の肺血管攣縮と肺血 管中膜の筋性肥大，さらには二次的な血栓形成によっ て肺血管抵抗の著明な増大が認められる。また肺血管 の器質的な肥厚が不可逆的に進行するため, 肺血管抵 抗の増加による右室への後負荷が持続的かつ進行性に 増大する.これに対し, 右室筋は肥大することにより 収縮力を強め右室拍出量を維持しょうとするが, 後負 荷の増大が右室の限界に達したり進行が急速な場合, 右室は適応できなくなり, 右室㧍よび右房の拡張をき たし右心不全におちいる。

一方, 膠原病に伴う肺高血圧症 $(\mathrm{CPH})$ も $\mathrm{PPH}$ と 同様に前毛細血管性であり, PPH と病態や進行の過 程が類似している。膠原病患者において, 肺高血圧症 がある場合に予後が悪いことが, 混合性結合組織病 (MCTD)（図 3）とならんで(9), 強皮症患者でも報告 されている(10). 肺動脈性肺高血圧症には, 他にも, 先天性心疾患, 門脈高血圧, HIV 感染症などに伴うも のや, 新生児持続性肺高血圧症などが含まれる（図 2). 


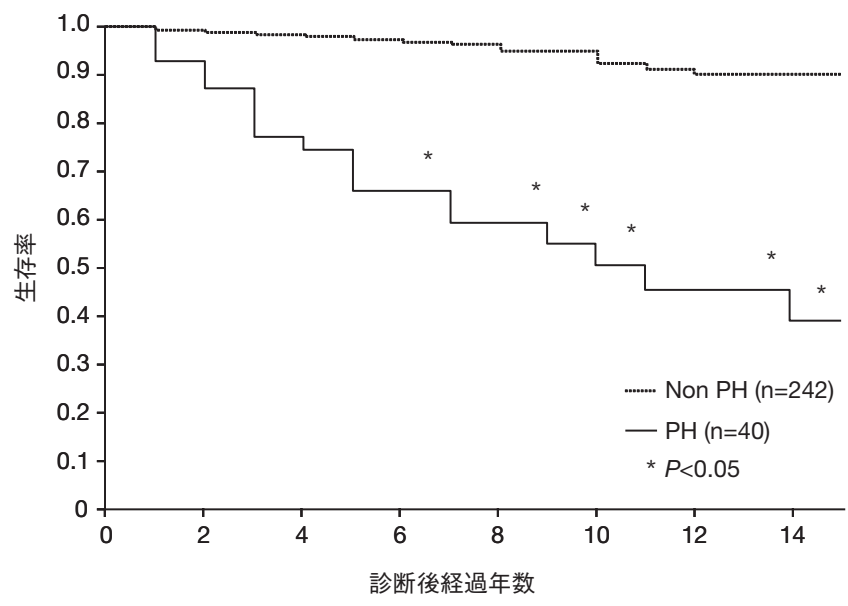

図 3 混合性結合組織病 (MCTD) 患者の予後に対する肺高 血圧症合併の影響（文献 9 より改变）

\section{4. 肺動脈性肺高血圧症の治療とプロスタサイ クリン療法}

肺動脈性肺高血圧症は極めて予後の悪い疾患であっ たため, 1976 年のプロスタサイクリン発見後, 既に 1980 年代前半には肺高血圧症に使用する試みが報告 されている(11). 当初肺移植へのつなぎと考えられて いたプロスタサイクリン静注療法は, 長期予後の改善 やQOLの改善などの効果が次々に明らかにされ，今 日では，本邦も含む各国で標準的治療法として位置づ けられている $(12)$.

しかしながら, 生体内において極めて速やかに分解 するプロスタサイクリンそのものを用いる限りは，投 与法として 24 時間の連続静脈内投与によるほかなか った。このため, インフュージョンポンプの操作の問 題, 冷却による薬液の安定性確保の問題, カテーテル 挿入部位の感染の問題など, 患者負担の面で改善の余 地が大きかったことも事実である(13).
このような状況下で，経口投与可能なプロスタサイ クリン誘導体である BPS の肺高血圧症への展開が期 待された，BPS 通常錠については，多施設共同の臨 床試験によって有効性が示され(14)，1999 年 9 月に 「原発性肺高血圧症」の効能追加承認を取得した。 BPS 通常錠の使用により, 肺血行動態 (14) をはじめ, 運動耐容能 (15) さらには長期予後の改善 (16) が示さ れている。現在では,「肺高血圧症治療ガイドライン $(2006$ 年改訂版 $) 」(12)$ にも記載されている.

\section{BPS の薬理学的特徵と作用メカニズム (17)}

肺動脈性肺高血圧症の発症および進行機序の詳細は, 現在なお不明な点が多いものの, その進行に, 肺細動 脈壁における血管作動性物質の相互作用が複雑に関与 することが明らかになっている(18). BPS は, (1)肺 動脈選択的な拡張作用, (2)血小板凝集抑制作用などの 抗血小板作用, (3)肺動脈平滑筋細胞の増殖抑制作用な どの薬理作用により, 肺動脈性肺高血圧症に効果を示 す. BPSの本症に対する作用メカニズムを図 4 に要 約する.

\section{1）作用メカニズム}

\section{(1)肺血管選択的な拡張作用}

肺動脈性肺高血圧症において, 肺細動脈の慢性的な 攣縮が肺動脈圧上昇の主因のひとつであることが広く 認められている(19)。肺高血圧症の血管拡張療法にお いて，体血圧の低下は好ましくないため，肺高血圧症 治療に用いる血管拡張薬は, より肺血管に選択的であ ることが望ましい. BPSの血管拡張作用を, セロト ニンによって収縮させたイ又摘出動脈(内皮剥離標本) を用いて in vitroで検討した. BPS は肺動脈を 1 $\mathrm{nmol} / \mathrm{L}$ から濃度依存的に弛緩させ，比較に用いた他 の部位の動脈に比べ, 肺動脈の $\mathrm{EC}_{50}$ 值が最も小さく なった（図 5)。また最大弛緩率も肺動脈が最も大き

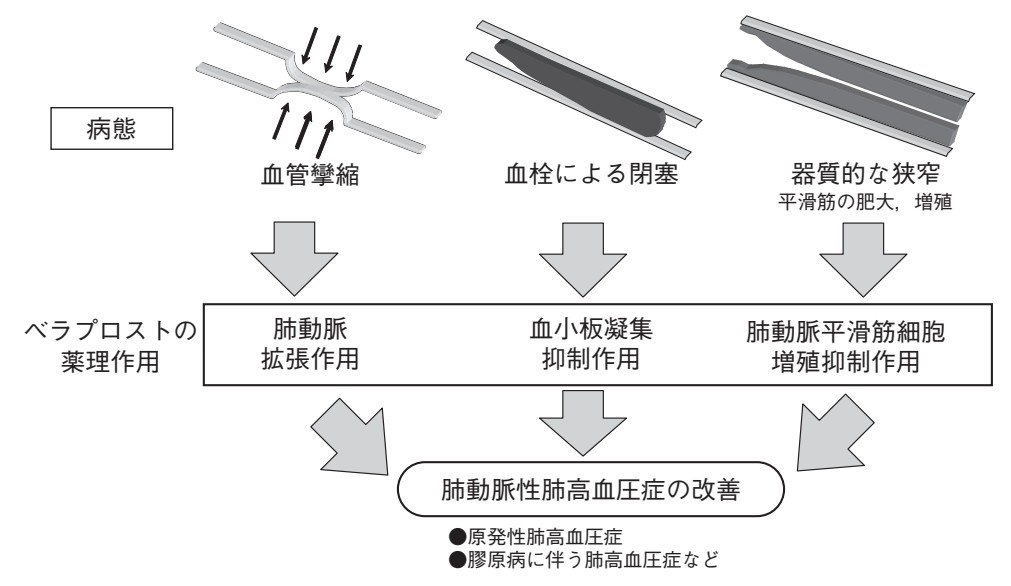

図 4 肺動脈性肺高血圧症に対する BPS の作用メカニズム 


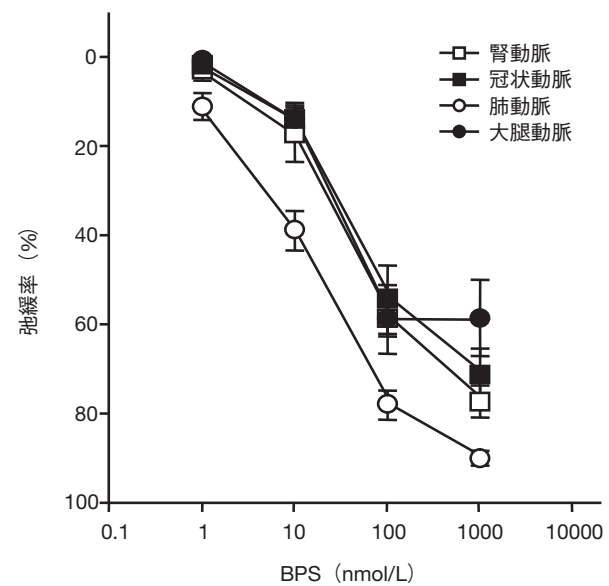

\begin{tabular}{|c|c|c|}
\hline $\begin{array}{c}\text { 血管の } \\
\text { 由来 }\end{array}$ & $\begin{array}{c}\mathrm{EC}_{50}\left(\times 10^{-8} \mathrm{~mol} / \mathrm{L}\right) \text { 钭) } \\
\left(-\log \mathrm{EC}_{50} \text { 標準誤差 }\right) \text { (例数) }\end{array}$ & $\begin{array}{c}\text { 最大弛緩率 } \\
(\%)\end{array}$ \\
\hline 冠 & $\begin{array}{c}3.42 \\
\left(7.47 \pm 0.11^{*}\right)(9)\end{array}$ & $71 \pm 6^{* *}$ \\
\hline 督 & $\begin{array}{c}3.39 \\
\left(7.47 \pm 0.14^{*}\right)(8)\end{array}$ & $77 \pm 4^{*}$ \\
\hline 大腿 & $\begin{array}{c}2.66 \\
(7.58 \pm 0.04)(7)\end{array}$ & $68 \pm 5^{\text {** }}$ \\
\hline 肺 & $\begin{array}{c}1.21 \\
(7.92 \pm 0.11)(21)\end{array}$ & $91 \pm 2$ \\
\hline
\end{tabular}

\section{図 5 イヌ摘出動脈のセロトニン収縮に対する弛緩作用}

左 : デー夕は $10^{-4} \mathrm{~mol} / \mathrm{L}$ のパパベリンによる弛緩反応を 100 としたときの割合を, 平均值士標準誤差で示した（セロトニン収縮の腎動脈：n $=8$, 冠状動脈 $: n=9$, 肺動脈 $: n=21$, 大腿動脈 $n=7$, 例数は標本数を示す). (文献 17 より引用)

右: ${ }^{*} P<0.05,{ }^{* *}: P<0.01$ vs. 肺動脈（Dunnett 検定）．註）各血管の最大弛緩率を 100\% としたとき，50\% 弛緩させるBPS の濃度を示した. (文献 17 より引用)

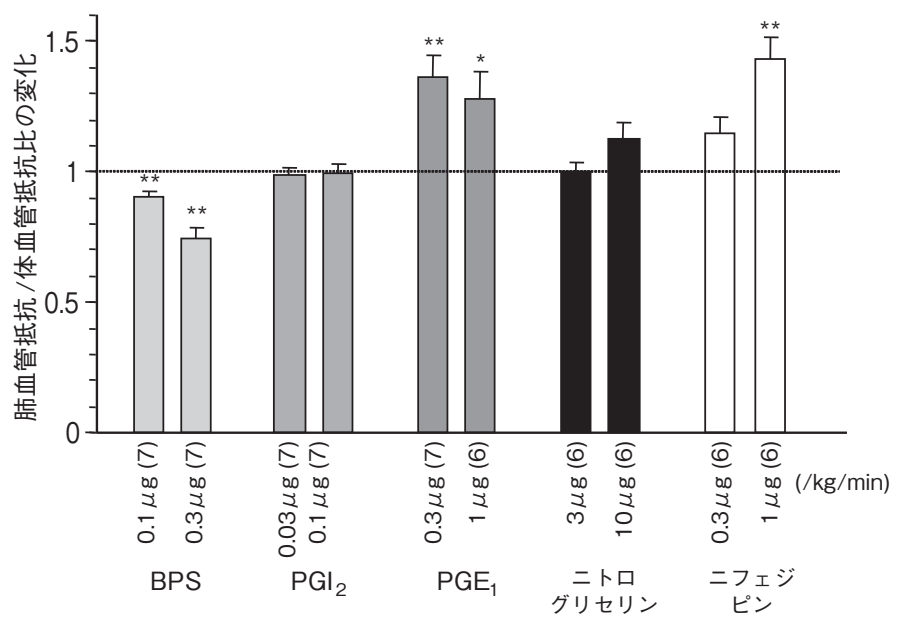

図 6 イヌ肺高血圧症モデルにおける各種血管拡張薬の肺血 管選択性

データは平均值士標準誤差で示した. 用量の後の（）内の数值 は例数を示した. ${ }^{*}: P<0.05,{ }^{* *}: P<0.01$ VS. 各血管拡張薬投 与前值（対応のある $t$ 検定）（文献 17 より引用）

くなった（図 5)。ささに，麻酔したイヌにトロンボ キサンアゴニストを持続投与することで作成した急性 肺高血圧症モデルを用いて，BPSの肺血管に対する 選択性を in vivo で検討した. BPSは，肺血管抵抗／ 体血管抵抗比を低下させ，肺血管により選択的な拡張 作用を有することが確認された $(20)$ 。一方比較に用い た血管拡張薬の $\mathrm{PGI}_{2}, \mathrm{PGE}_{1}$, ニトログリセリン，二 フェジピンでは肺血管への選択性は認められなかった (図 6).このようにBPSは, 肺血管により選択的な 血管拡張作用という, 肺高血圧症治療に好ましい性質 を有している.

\section{(2)抗血小板作用}

肺高血圧症患者の肺組織には高率に微小血栓が存在
することから，本症の発症および進行における，肺微 小血栓による血管閉塞の重要性が指摘されている (19). 血栓形成には血小板が極めて重要な役割を果たすが, BPS は広範な抗血小板作用によって, 肺細血管にお ける血栓形成を抑制する。プロスタサイクリンの抗血 小板作用は，全血中で増加する (21)，そこで，全血中 にBPSを添加した後に多血小板血漿を調製し次いで 凝集惹起剤の ADP を添加するという, 血小板凝集の 評価法 (22) を構築した。この, 生体内環境を反映さ せた in vitro 評価系によって BPS の凝集抑制作用を評 価したところ，BPSは ADP $1.5 \mu \mathrm{mol} / \mathrm{L}$ 刺激時には $0.048 \mathrm{nmol} / \mathrm{L}$ ( 約 $20 \mathrm{pg} / \mathrm{mL}$, BPS 分子量 約 420), ADP $2.5 \mu \mathrm{mol} / \mathrm{L}$ 刺激時には $0.095 \mathrm{nmol} / \mathrm{L}$ (約 $40 \mathrm{pg} / \mathrm{mL}$ ) 以上の濃度で凝集を抑制した（図 7)。

さらに，本剤の抗血小板作用を ex vivo で評価する ため，健康成人男子を対象として，本郕 $120 \mu \mathrm{g}$ ある いはプラセボを食後単回経口投与したときの血小板凝 集抑制作用を，単盲検クロスオーバー法で比較した。 本剂 $120 \mu \mathrm{g}$ の食後投与によって，血小板凝集抑制作 用は少なくとも 12 時間持続すること, 12 時間後の BPS の血漿中濃度が，上述した in vitroに扔ける最小 有効濃度にほぼ相当することが確認された（図 7)。

\section{(3)血管平滑筋細胞増殖抑制作用}

肺高血圧症患者では，肺高血圧状態の持続や肺血管 内皮細胞の障害が原因となる肺細動脈の器質的な狭窄 が, 病態の不可逆的な悪化に重要であり, ヒト剖検例 でも高率に認められる $(23)$ 。この変化には，肺高血圧 の持続だけでなく，血管内皮細胞の障害や，血小板か ら放出される血小板由来増殖因子（PDGF）などによ る血管平滑筋細胞の増殖の立進が深く関与している 

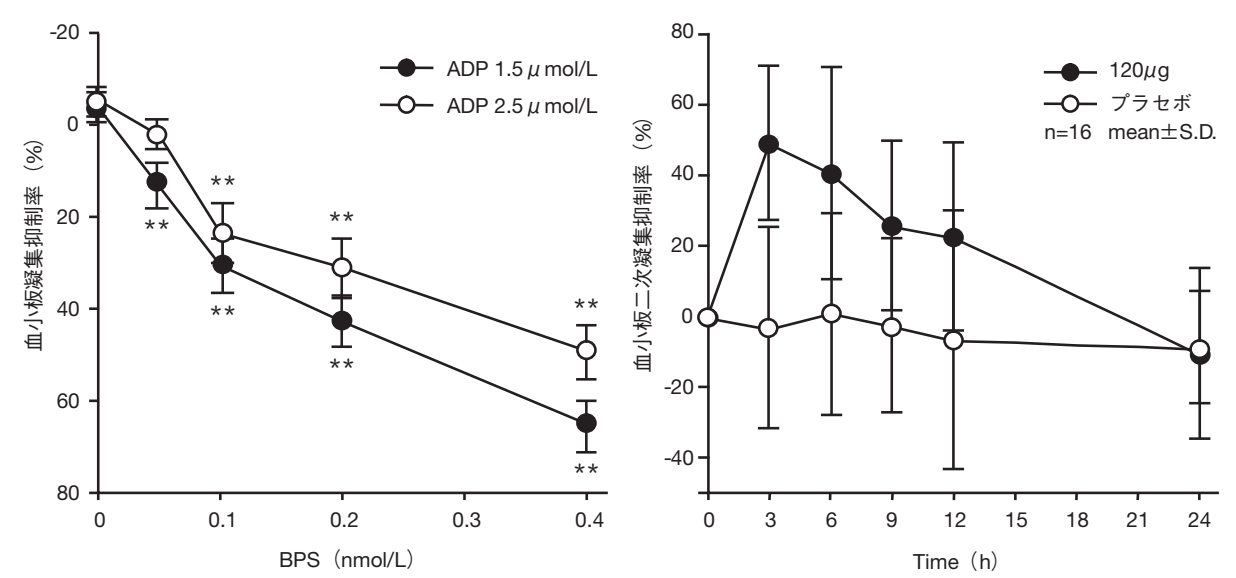

図 7 ヒト血小板凝集抑制作用（in vitro），および本剤 $120 \mu \mathrm{g}$ またはプラセボ投与時の血小板凝集抑制作用（ex vivo）

左: デー夕は無処理時の凝集に対する抑制率を, 平均值士標準誤差で示した $(\mathrm{n}=9)$. ${ }^{* *}: P<0.005$ (VS. ベラプロストナトリウム $0 \mathrm{nmol} / \mathrm{L}$ ) (Shirley-Williams 検定). (文献 32 より引用)

右：データは投与直前の血小板凝集抑制率を 0 としたときの割合を，平均值士標準偏差で示した $(n=16)$. 投与後 12 時間目の血小板凝集率. プラセボー6.7 $\pm 36.6 \%$, 本剤 $120 \mu \mathrm{g}, 22.6 \pm 26.8 \% . P=0.014$ （ $t$ 検定）。（文献32 より引用）

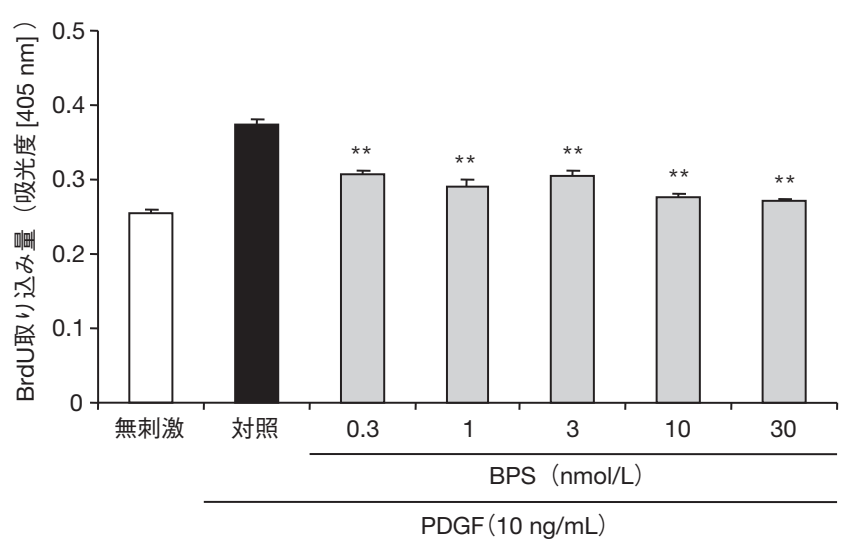

図 8 ヒト血管平滑筋細胞增殖抑制作用（in vitro） データは平均值土標準誤差で示した $(n=3-4)$.

** : $P<0.01$ vs. 対照群（Dunnett 検定）（文献 17 より引用）

(24)．後述するように，モノクロタリン誘発ラット肺 高血圧症モデルにおいて, BPSの慢性投与により, 肺細動脈の器質的な狭窄が抑制されることが確認され ているが，この効果には，BPSが肺血管拡張作用に よって肺動脈圧を低下させるだけでなく，抗血小板作 用によって血小板からの PDGF 放出を抑制すること, 血管平滑筋細胞増殖を直接抑制することが寄与してい る. BPSの血管平滑筋細胞増殖抑制作用を確認する ため, PDGF $(10 \mathrm{ng} / \mathrm{mL})$ の刺激によるヒト肺動脈血 管平滑筋細胞の増殖に対する効果を, 5-ブロモ-2’デ オキシーウリジン (BrdU) の取り达みによって評価し た. BPSは $0.3 \mathrm{nmol} / \mathrm{L}$ から増殖を抑制し, 本剤の臨 床血漿中濃度範囲で抑制効果が認められた（図 8)。

\section{2) 病態モデルに対する作用}

(1)ラットモノクロタリン誘発肺高血圧症モデル

肺高血圧症モデルとして沉用される，モノクロタリ
ン誘発ラットを用いて BPS の効果を検討した。本モ デルは，モノクロタリンを投与することによって，肺 の内皮細胞に障害を引き起こすもので，この障害が引 き金となって血小板の活性化, 肺血管の血管収縮物質 に対する反応性の克進, 肺血管の器質的狭窄などが生 じる. その後, 肺動脈圧の急激な上昇, 右心肥大や肺 細血管の閉塞性病変が進行し, 最終的に全個体が死亡 するなど，ヒトの病態を良く反映している(25).

本モデルにおいて, BPSの経口投与により右室収 縮期圧の上昇が用量依存的に抑制され, $0.1 \mathrm{mg} / \mathrm{kg} /$ 日投与群では対照群に比べて有意であった（図 9).

また本モデルにBPSを $6 \mu \mathrm{g} / \mathrm{mL} 3$ 週間飲水投与（投 与量 : $354 \pm 17 \mu \mathrm{g} / \mathrm{kg} /$ 日. 平均值 \pm 標準偏差）した ところ, 肺動脈圧の上昇が抑制された。また， $3 \mu \mathrm{g} /$ $\mathrm{mL}, 6 \mu \mathrm{g} / \mathrm{mL}$ それぞれ 1 週間飲水投与 $(244 \pm 7 \mu \mathrm{g} /$ $\mathrm{kg} /$ 日， $415 \pm 19 \mu \mathrm{g} / \mathrm{kg} /$ 日）あるいは 3 週間飲水投 与 $(205 \pm 27 \mu \mathrm{g} / \mathrm{kg} /$ 日, $354 \pm 17 \mu \mathrm{g} / \mathrm{kg} /$ 日) によって, 肺血管中膜の筋性肥大が抑制された（17）。また別に, BPS の投与によって生存率が改善するとの報告もな されている(26).

\section{(2)ラット塞栓誘発肺高血圧症モデル}

肺高血圧症の増悪に肺微小血栓が寄与することから, コラーゲンを静脈内に投与して肺塞栓を惹起した塞栓 誘発ラット肺高血圧症モデルにおけるBPSの効果を 検討した. BPSの十二指腸内投与により, $0.03 \mathrm{mg} /$ $\mathrm{kg}$ から右室収縮期圧上昇の抑制が認められた（図 9).

\section{(3)イヌトロンボキサン誘発肺高血圧症モデル}

肺動脈性肺高血圧症の発症や増悪の原因となる肺細 動脈の持続的な攣縮に, トロンボキサンの関与が指摘 されている(27). そこで, トロンボキサンアゴニスト 

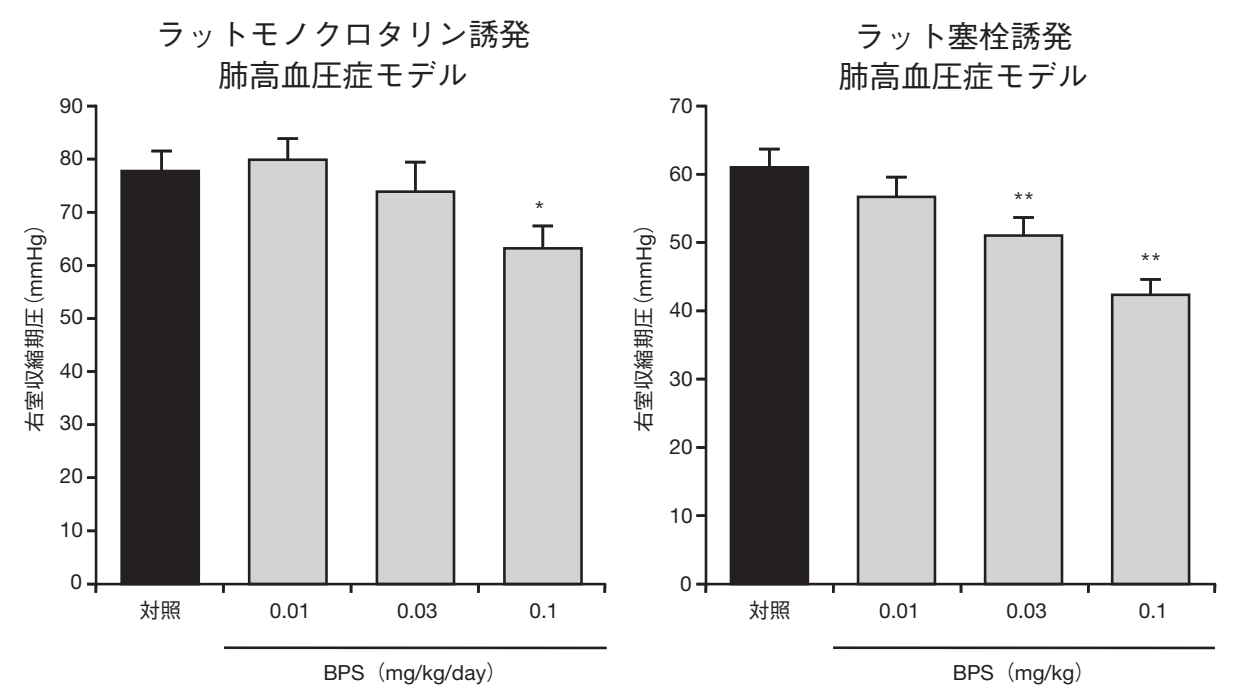

図 9 モノクロタリンおよび塞栓誘発肺高血圧症モデルラットの右室収縮期圧上昇に対する作用

左 : デー夕は平均值土標準誤差で示した $(n=16-17) .{ }^{*}: P<0.05 \mathrm{vs}$. 対照群（Dunnett 検定）(文献 17 より引用)

右：デー夕は平均值士標準誤差で示した $(n=15) .{ }^{* *}: P<0.01$ vs. 対照群（Dunnett 検定）（文献 17 より引用）
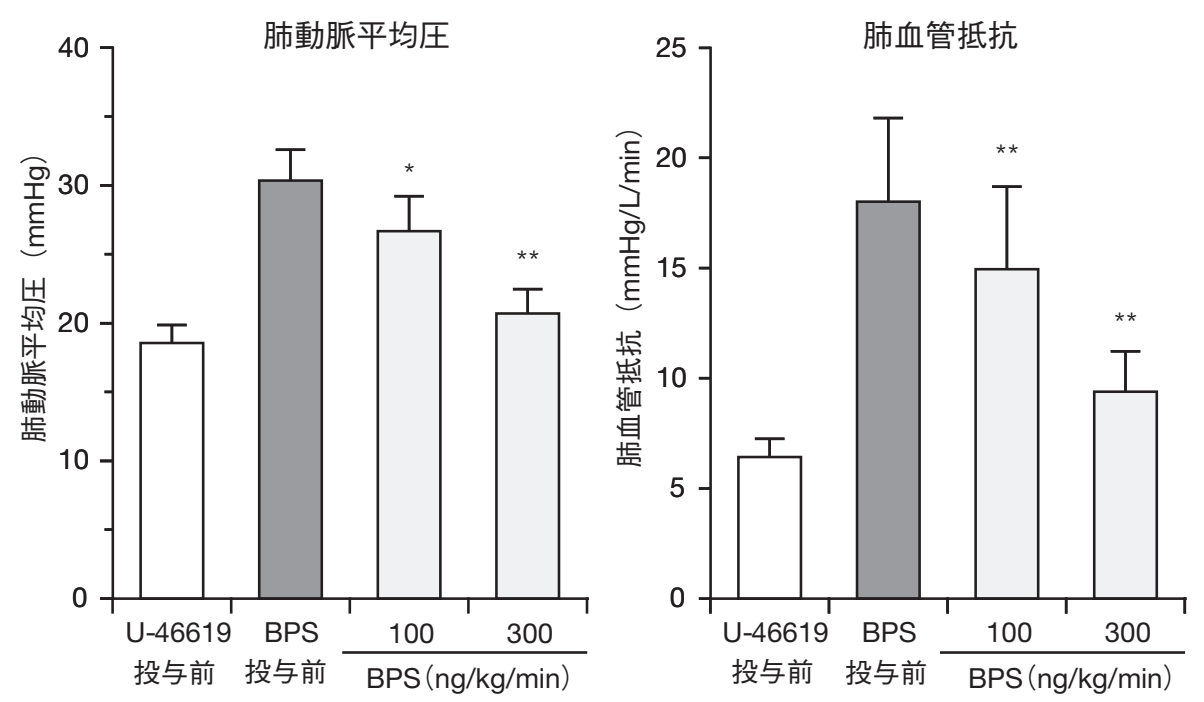

図 10 トロンボキサンアゴニスト誘発肺高血圧症モデルイヌの肺動脈圧および肺血管抵抗に対する作用

デー夕は平均值士標準誤差で示した $(n=7) .{ }^{*}: P<0.05,{ }^{* *}: P<0.01$ BPS 投与前との比較（対応のある $t$ 検定）。(文献 32 より引用）

を持続注入することでイヌ肺高血圧症モデルを作成し た. 本モデルにBPSを静脈内持続投与したところ, $100 \mathrm{ng} / \mathrm{kg} / \mathrm{min}$ より肺動脈圧および肺血管抵抗の低下 が認められた（図 10）(17).

\section{BPS 徐放性製剤の目標血漿中濃度推移}

プロスタサイクリン注射剂や BPS 通常錠などを用 いた肺高血圧症患者のプロスタサイクリン療法に扔い ては, 病態の重篤性も考慮し, 通常忍容できる最大用 量を投与することが治療の基本となっている. BPS 通常錠における 1 回最大投与量は, 主に頭痛, 顔面紅 潮，ほてりなど BPS の血管拡張作用に基づく $\mathrm{C}_{\max }$ 依 存的な副作用によって規定され, 1 回用量は $60 \mu \mathrm{g}$ が
最大であった。 また, BPSの血漿中からの消失半減 期が約 1 時間と短いことから, 肺高血圧患者の治療に は, BPS 通常錠を 1 日 3 ～回投与することが必要 であり，1 日 6 回投与での治療例も報告されている (28).このため, 患者の利便性の向上とともに, 治療 効果の向上を期待する徐放性製片が求められていた.

本剤の目標とする血漿中濃度推移は，まず有効性の 面から，次のように設定した。

上述したように，肺高血圧症の治療効果に結びつく BPSの主な薬理作用としては, 肺血管拡張作用, 血 小板凝集抑制作用などの抗血小板作用, 肺血管平滑筋 細胞の増殖抑制作用があげられる. In vitroにおける ヒトの肺血管拡張作用（イヌでの結果（図 5) と，プ 
ロスタサイクリンのヒト肺血管拡張作用の $\mathrm{EC}_{50}$ 值が イヌの約 0.14 倍である(29) ことからの推定值), 血 小板凝集抑制作用ならびに平滑筋細胞増殖抑制作用は, いずれも通常錠投与時の血漿中 BPS 濃度範囲内では 飽和することなく濃度依存的に増加した。

また，肺高血圧症患者に BPS 通常錠を投与した際 の肺血管抵抗の低下（BPS の肺血管拡張作用を反映 すると考えられる）の時間推移(30) が, BPS 通常錠 投与後のBPSの血漿中濃度推移と並行して認められ ることから, BPSの血小板凝集抑制作用および肺血 管拡張作用と薬物濃度との関係は, in vitro と ex vivo あるいは in vivo でほほ同様であると考えられた。こ の点は，ヒトに本剤を投与した際の血漿中 BPS 濃度 と血小板凝集抑制作用の関係が, in vitroでの関係と ほほ同様であったことからも確認された。

以上の知見から, BPSの有効性を向上させるため には，本剤の最小有効濃度以上のできるだけ高い血漿 中濃度を 24 時間持続させることが重要であると考えた。

In vitro での最小有効濃度は，ヒト血小板凝集抑制 作用で約 0.05-0.1 nmol/L (20-40 pg/mL) である（図 7). 肺血管拡張作用（上述したイヌでの結果からのヒト推 定值), ヒトでの平滑筋細胞増殖抑制作用（図 8）も ほぼ同様の濃度から認められることから, 本濃度を BPSの治療域の下限に設定した.

上述したようにBPS 製剤の投与量は，主に血管拡 張作用に基づく $\mathrm{C}_{\max }$ 依存的な副作用によって規定さ れる.このため, BPS 通常錠での 1 回最大投与量で ある $60 \mathrm{~g}$ 投与時の $\mathrm{C}_{\max }$ を超えなければ安全性の確保 が可能であると判断し, 約 $400 \mathrm{pg} / \mathrm{mL}$ を治療域の上 限に設定した。

以上より, 本剤の安全性を確保しつつ有効性を向上 させるためには，血漿中濃度を 20 から $400 \mathrm{pg} / \mathrm{mL}$ の 治療域範囲内で, できるだけ高く維持することが重要 であると考え，目標とする血漿中濃度推移とした。

\section{BPS 徐放性製剤の製剤設計}

プロスタグランジン類は, 物理・化学的, ならびに 生物学的特性を改善した各種の誘導体や製剤が開発さ れ, 臨床応用されている. しかしながら, いずれも血 漿中半減期が $0.5 \sim 1$ 時間前後と一般の薬剤に比べ短 いことや，消化管内での安定性や吸収性が十分でない 薬剤が多いことから，世界的にもプロスタグランジン 系薬剂の経口徐放性製剤の例はない.

BPS は, その物理・化学的特性として, 水に対す る高い溶解性と広範囲の $\mathrm{pH}$ における良好な安定性を 有している。また, in situ下のラットにおける吸収部
位特性の評価において，胃での吸収性は低いが，十二 指腸および空腸において良好な吸収性を示す。したが って，このような BPSの特性を利用すれば，消化管 内での製剤からの薬物溶出を制御することにより，任 意の血漿中薬物濃度範囲を維持できると判断した。し かしながら, BPSのヒトでの血漿中消失半減期は約 1 時間と短いことから, 製剤の消化管移動時間も考慮し, 1 日 2 回型製剤を目標とした.

まず，既存の徐放化システムとして知られている各 種剂型を, in vitro およびヒトを含む in vivo で評価し, 水溶性高分子を使用したハイドロゲルマトリックス処 方が有望と判断した。本処方は, ゲル中の拡散とゲル の浸食溶解（エロージョン）により吸収を制御するた め, 短時間でゲル化する処方とすることができれば, 製剤からの安定した薬物放出と製剤の利用率向上が期 待できる，他方，消化管下部に移動するにつれて，薬 物溶出に必要な消化液水分量が少なくなるため, 消化 管下部での溶出性や生物学的利用率が低下するおそれ がある。この点についても考慮し, BPSに必要とさ れる消化管内での安定した徐放性および吸収性を長時 間維持するために，1消化液の $\mathrm{pH}$ に影響を受けにく い溶出, (2)消化管内での速やかなゲル化, (3)消化管内 の移動にともなうゲル中の拡散とゲルの浸食溶解によ る薬物溶出, という特徵を有する 1 日 2 回型ハイドロ ゲルマトリックス徐放性製剤とすることとした，本目 的を達成するため, ポリエチレンオキシド $5000 \mathrm{~K} を$ 基材とし，マクロゴール 6000, L-グルタミン酸を含 有する製剤とした。

次に, この設計コンセプトを満足する製剤処方を, in vitro（溶出性, ゲル化能, 安定性）および in vivo（イ ヌ）での特性評価に基づいて設定した。最終的に，錠 剤中のポリエチレンオキシド $5000 \mathrm{~K}$ 配合量の異なる 2 種類の候補製剤を治験薬として試作し, ヒトにおける 製剤スクリーニング試験を実施して開発処方を決定す ることとした。試験は, 健康成人男子 16 名を対象と して，120 $\mathrm{g}$ の空腹時単回経口投与で実施した。本 検討の結果, 両処方共に目標に近い溶出パターンを示 し，消化管内において $\mathrm{pH}$ 変動の影響を受けにくく， 安定した溶出速度を有することが明らかになった。こ のうち, 生物学的利用能ならびに持続性の面でより目 標の性能に近い処方を選択し, 開発コードTRK100STP として以下の臨床開発を行った. 図 11 に本剂 の徐放メカニズムを, 図 12 に本剂と BPS 通常錠を比 較した際の, 血漿中濃度の模式図を反復投与時の実測 值に基づいて示した. 

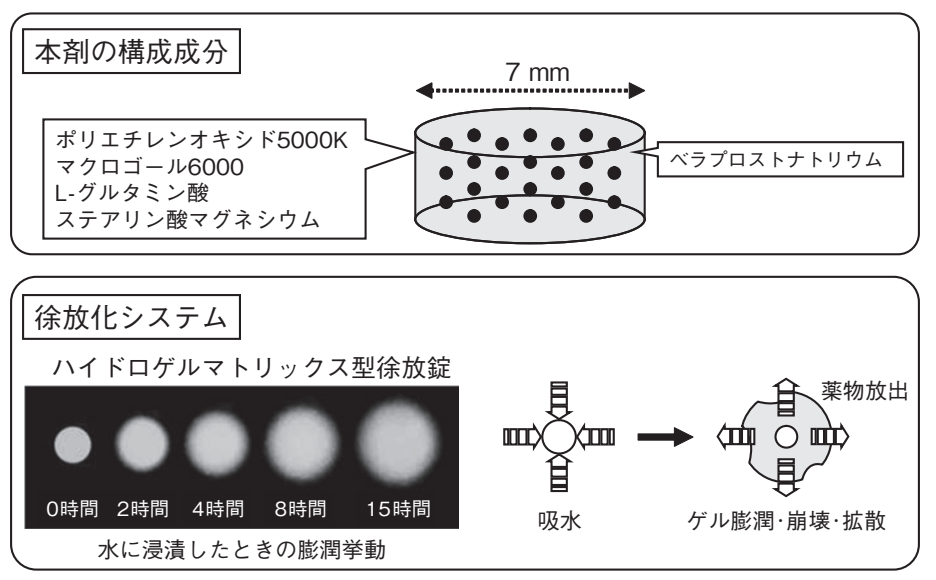

図 11 本剤の徐放メカニズム

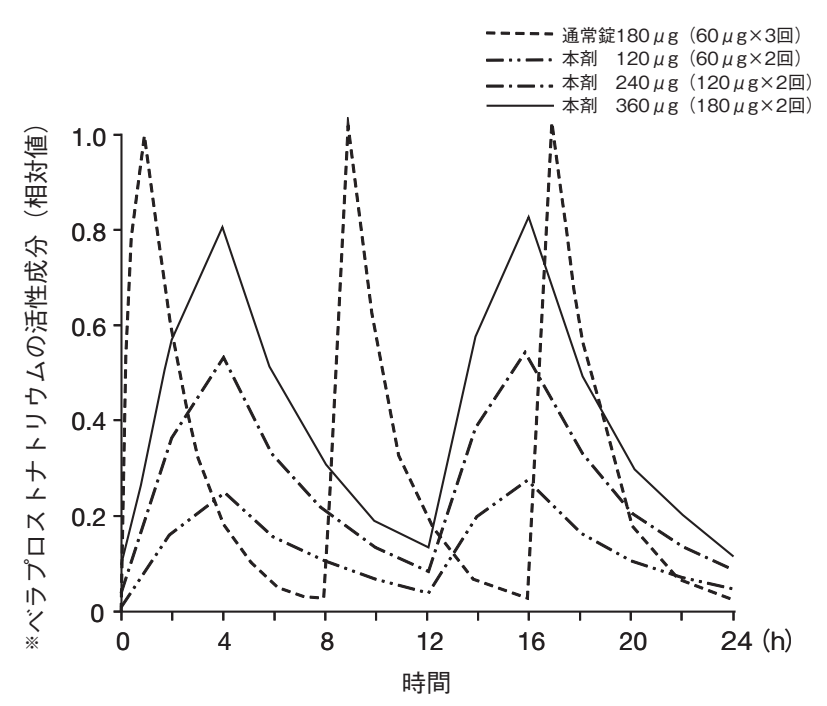

図 12 本剂および BPS 通常錠反復投与時の血漿中濃度推移 （第।相試験結果に基づく模式図）

※通常錠でのべラプロストナトリウム活性成分の $C_{\max }$ を 1 とし た時の相対比較

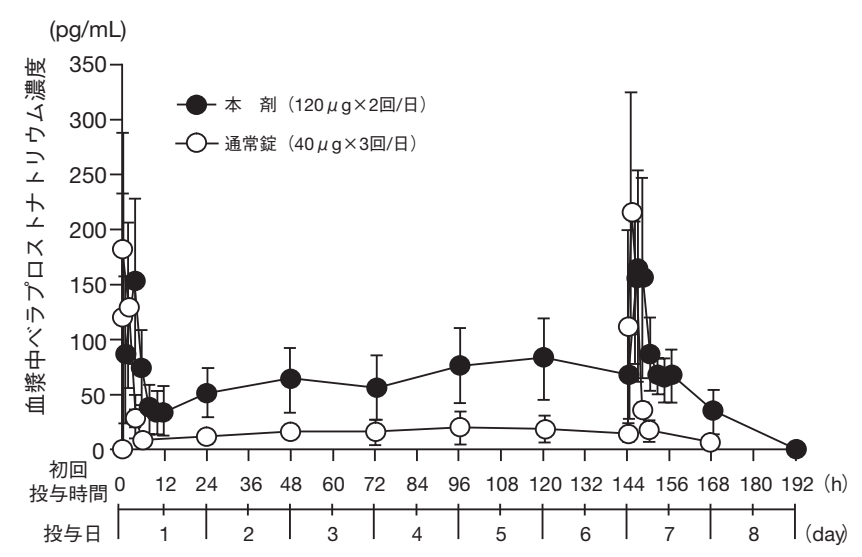

図 13 本剤 $120 \mu \mathrm{g}, 1$ 日2 回および, BPS 通常錠 40 $\mu \mathrm{g}, 1$ 日 3 回反復投与時の血漿中濃度推移

デー夕は平均值土標準偏差で示した（各 $\mathrm{n}=12$ )。（文献 32 より 引用)

\section{8. 臨床試験}

\section{1）第 I 相臨床試験 \\ (1) 単回投与}

健康成人に, 本剤 $120 \mu \mathrm{g}$ または $180 \mu \mathrm{g}$ を食後経口 単回投与した際の, BPSの血漿中濃度は, $\mathrm{C}_{\max }$ の平 均值がそれぞれ $178.5,264.5 \mathrm{pg} / \mathrm{mL} ， \mathrm{~T}_{\max }$ は 3.2 , 3.9 時間であった.

\section{(2) 反復投与}

健康成人を対象として, 本郕 1 回 $120 \mu \mathrm{g}$ を 1 日 2 回 7 日間食後反復投与時の薬物動態と, BPS 通常錠 1 回 $40 \mu \mathrm{g}$ を 1 日 3 回 7 日間食後反復投与時の薬物動態 をクロスオーバー法で比較した。本剂 1 回 $120 \mu \mathrm{g}$ を 1 日 2 回 7 日間食後反復投与時の血漿中濃度は, 投与 3 日目には定常状態に達し, 蓄積性は認められなかっ た（図 13，表 1).

本剂と BPS 通常錠の薬物動態を比較したところ, 本剂投与群の 7 日目の $\mathrm{C}_{\max }$ は $\mathrm{BPS}$ 通常錠群に比べて 有意に低く，血漿中濃度の変動を示す $\mathrm{C}_{\max }$ と $\mathrm{C}_{\min }$ の差は有意に小さく, AUC は BPS 通常錠に比べ 2 倍 程度大きかった．本郕の BPS 通常錠に対する相対的 バイオアベイラビリティは, 初回投与時で $59.1 \%$, 投 与 7 日目で $75.9 \%$ であった，以上のことから, 本凨の 良好な徐放特性が確認された。

\section{2) 第 II 相臨床試験 $(31,32)$}

\section{(1)概要}

原発性肺高血圧症（PPH）抢よび膠原病に伴う肺高 血圧症（CPH）の患者における本剤の有効性および 安全性を第 II 相試験で評価した。対象は PPH 25 例,

$\mathrm{CPH} 19$ 例であり, 心機能の重症度を示す WHO 機能 分類ではクラス I 〜 III (I：6 例, II $: 28$ 例, III $： 10$ 例 $)$ であった。また BPS 通常錠の治療歴ありの被験者は 35 例, 平均肺動脈圧 $(44$ 例）は $46.8 \pm 14.2 \mathrm{mmHg}$ （平 
表 1 本剤および BPS 通常錠反復投与時の血漿中濃度パラメータ

\begin{tabular}{|c|l|c|c|c|c|}
\hline \multicolumn{2}{|c|}{} & $\begin{array}{c}\mathrm{C}_{\max } \\
(\mathrm{pg} / \mathrm{mL})\end{array}$ & $\begin{array}{c}\mathrm{T}_{\max } \\
(\mathrm{h})\end{array}$ & $\begin{array}{c}\mathrm{AUC}_{0-\mathrm{t}}{ }^{*} \\
(\mathrm{pg} \cdot \mathrm{h} / \mathrm{mL})\end{array}$ & $\begin{array}{c}\mathrm{C}_{\min } \\
(\mathrm{pg} / \mathrm{mL})\end{array}$ \\
\hline \multirow{2}{*}{1 日目 } & 本剤 $(120 \mu \mathrm{g} \times 2$ 回 /日) & $170.4 \pm 63.1$ & $4.2 \pm 2.6$ & $810 \pm 295$ & $34.9 \pm 23.1$ \\
\cline { 2 - 6 } & 通常錠 $(40 \mu \mathrm{g} \times 3$ 回 /日) & $228.4 \pm 94.6$ & $1.3 \pm 0.6$ & $462 \pm 144$ & $9.0 \pm 7.5$ \\
\hline \multirow{2}{*}{7 日目 } & 本剤 $(120 \mu \mathrm{g} \times 2$ 回 /日) & $214.7 \pm 89.1$ & $3.0 \pm 1.0$ & $1225 \pm 344$ & $68.4 \pm 39.6$ \\
\cline { 2 - 6 } & 通常錠 $(40 \mu \mathrm{g} \times 3$ 回 /日 $)$ & $242.2 \pm 81.4$ & $1.2 \pm 0.5$ & $550 \pm 148$ & $14.9 \pm 6.7$ \\
\hline
\end{tabular}

データは平均值士標準偏差で示した（各 $\mathrm{n}=12 ）$ ． *本剤 $\mathrm{AUC}_{0-12 \mathrm{~h}}$, 通常錠 $\mathrm{AUC}_{0-6 \mathrm{~h}}$ を示す。（文献 32 より引用）

表 26 分間歩行距離の 0 週に対する 12 週（または中止時）の差に対する本剤の効果

\begin{tabular}{|c|c|c|c|c|}
\hline \multirow{3}{*}{ 解析対象 } & \multirow{3}{*}{ 例数 } & \multicolumn{3}{|c|}{ 6分間歩行距離 (m) } \\
\hline & & \multicolumn{2}{|c|}{ 測定時期 } & \multirow{2}{*}{$\begin{array}{l}\text { 0週に対する12週 } \\
\text { (または中止時)の差 }\end{array}$} \\
\hline & & 0週 & 12週 (または中止時) & \\
\hline 全症例 & 44 & $\begin{array}{c}402.1 \pm 124.6 \\
{[364.2,440.0]}\end{array}$ & $\begin{array}{c}435.6 \pm 121.0 \\
{[398.8,472.4]}\end{array}$ & $\begin{array}{c}33.4 \pm 66.0 \\
{[13.4,53.5]}\end{array}$ \\
\hline PPH & 25 & $\begin{array}{c}428.2 \pm 119.3 \\
{[378.9, \quad 477.4]}\end{array}$ & $\begin{array}{c}442.6 \pm 123.4 \\
{[391.6, \quad 493.5]}\end{array}$ & $\begin{array}{c}14.4 \pm 49.8 \\
{[-6.2, \quad 35.0]}\end{array}$ \\
\hline $\mathrm{CPH}$ & 19 & $\begin{array}{c}367.9 \pm 126.3 \\
{[307.0,428.8]}\end{array}$ & $\begin{array}{c}426.4 \pm 120.5 \\
{[368.3,484.5]}\end{array}$ & $\begin{array}{c}58.5 \pm 77.0 \\
{[21.4,95.6]^{*}}\end{array}$ \\
\hline
\end{tabular}

$\mathrm{CPH}$ ：膠原病に伴う肺高血圧症， PPH：原発性肺高血圧症. デー夕は平均值士標準偏差および $[95 \%$ 信頼区間 $]$ で示した. * : $95 \%$ 信頼区間において 0 を含まないため有意 $(P<0.05)$ とみなした. (文献 32 より引用 $)$

表 3 右心カテーテル検査による肺血行動態に対する本剤の効果

\begin{tabular}{|c|c|c|c|}
\hline & \multicolumn{2}{|c|}{ 測定時期 } & \multirow{2}{*}{$\begin{array}{c}\text { 投与開始前に対する } \\
\text { 投与終了後 } \\
\text { (または中止時)の差 }\end{array}$} \\
\hline & 投与開始前 & $\begin{array}{c}\text { 投与終了後 } \\
\text { (または中止時) }\end{array}$ & \\
\hline $\begin{array}{c}\text { 平均肺動脈圧 } \\
(\mathrm{mmHg})\end{array}$ & $\begin{array}{c}46.8 \pm 14.2 \\
{[42.5,51.1]}\end{array}$ & $\begin{array}{c}44.0 \pm 14.3 \\
{[39.3,48.6]}\end{array}$ & $\begin{array}{c}-2.8 \pm 5.5 \\
{[-4.6, \quad-1.0]^{*}}\end{array}$ \\
\hline $\begin{array}{c}\text { 全肺血管抵抗 } \\
(\mathrm{mmH} / \mathrm{L} / \mathrm{L} \cdot \mathrm{min})\end{array}$ & $\begin{array}{c}12.97 \pm 6.85 \\
{[10.87, \quad 15.08]}\end{array}$ & $\begin{array}{c}11.26 \pm 5.27 \\
{[9.55, \quad 12.97]}\end{array}$ & $\begin{array}{c}-0.92 \pm 2.63 \\
{[-1.78, \quad-0.05]^{*}}\end{array}$ \\
\hline $\begin{array}{c}\text { 肺血管抵抗係数 } \\
\left(\mathrm{mmHH} / \mathrm{L} \cdot \mathrm{min} \cdot \mathrm{m}^{2}\right)\end{array}$ & $\begin{array}{c}15.0 \pm 7.6 \\
{[12.6, \quad 17.4]}\end{array}$ & $\begin{array}{c}13.3 \pm 7.6 \\
{[10.8, \quad 15.8]}\end{array}$ & $\begin{array}{c}-1.2 \pm 3.9 \\
{[-2.5,0.1]}\end{array}$ \\
\hline
\end{tabular}

データは平均値士標準偏差および [95\%信頼区間］で示した。

* : $95 \%$ 信頼区間において 0 を含まないため有意 $(P<0.05)$ とみなした。（文献 32 より引用 $)$

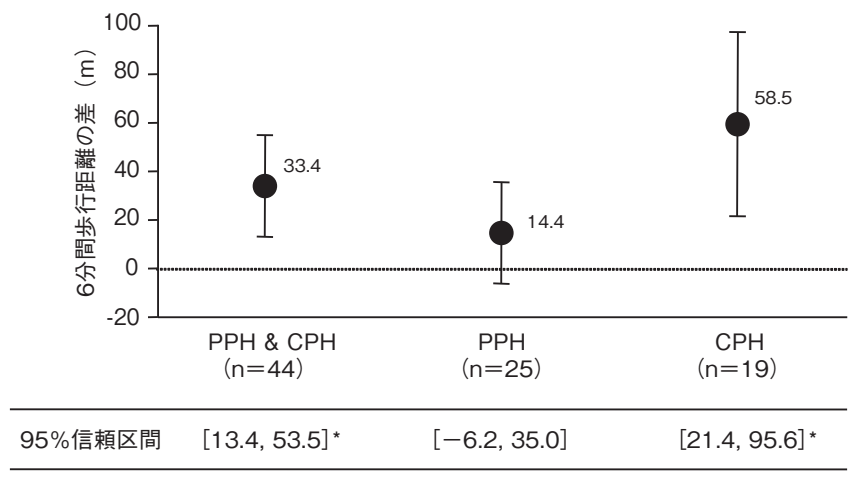

図 146 分間歩行距離の 0 週に対する 12 週（または中止時） の差に対する本剤の効果

$\mathrm{PPH}$ : 原発性肺高血圧症, $\mathrm{CPH}$ ：膠原病に伴う肺高血圧症, データは平均值士標準偏差および [95\%信頼区間] で示した * : 95\%信頼区間において 0 を含まないため有意 $(P<0.05)$ とみ なした. (文献 32 より引用)
均值士標準偏差）であった。

投与方法としては，本剤を 1 日 $120 \mu \mathrm{g}(60 \mu \mathrm{g} \times 2$ 回）から投与開始し, 1 週間毎に 1 日 $240 \mu \mathrm{g}(120 \mu \mathrm{g}$ $\times 2$ 回 $), 1$ 日 $360 \mu \mathrm{g}(180 \mu \mathrm{g} \times 2$ 回 $)$ と増量した。た だし，投与を継続できない場合は，1段階減量し維持 用量とした，投与期間は 85 日間とした。

\section{(2)結果}

有效性解析対象は 44 例, 安全性解析対象は 46 例で あった. 主要評価項目の「6 分間歩行距離の差」は, 投与開始前に比べ平均 $33.4 \mathrm{~m}$ 延長した. $95 \%$ 信頼区 間の下限は 0 を上回り, この変化は有意であった。こ のうち膠原病に伴う肺高血圧症では延長は平均 58.5 $\mathrm{m}$, 原発性肺高血圧症での延長は平均 $14.4 \mathrm{~m}$ であっ た（図 14，表 2).

副次評価項目として, 肺血行動態に対する効果を右 


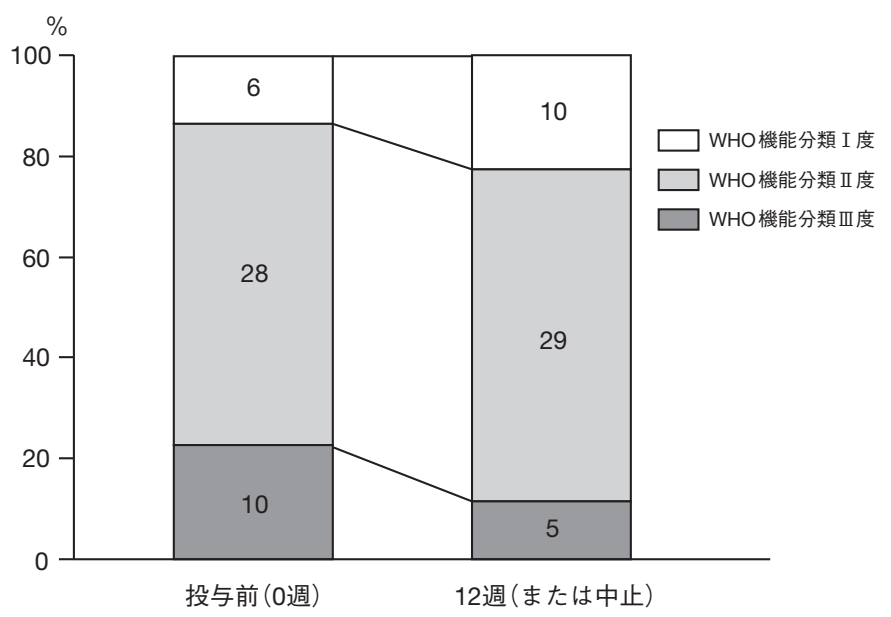

図 15 WHO 心機能分類に対する本剤の効果 グラフ内の数值は例数

心カテーテル検查によって検討した（表 3). 肺動脈 圧の平均值は, 投与前 $46.8 \mathrm{mmHg}$ であったが, 本剤 投与終了後（または中止時）には $44.0 \mathrm{mmHg}$ に低下 した．投与開始前との差は平均 $-2.8 \mathrm{mmHg}$ であり, この変化は有意であった，全肺血管抵抗は本剂投与終 了後（または中止時），投与開始前に比べ平均 0.92 $(\mathrm{mmHg} / \mathrm{L} \cdot \mathrm{min})$ 低下し, この変化は有意であった. 肺血管抵抗係数は改善の傾向は認めたものの, 有意で はなかった。

心機能を示す WHO 機能分類においては, 本剤の投 与により, クラス I の割合が増加し, クラス III の割 合が減少する傾向が認められた（図 15）.

ヒト脳性ナトリウム利尿ペプチド（BNP）は右心 負荷の良い指標であり，その上昇は肺高血圧症患者の 予後の悪化と関係する (33). 本剤の長期投与に扔ける BNP の患者ごとの変化を示す (図 16). 第 II 相臨床 試験症例(46 例) のうち, 4 例は 183 日〜 364 日, 4 例は 365 日〜 546 日，31 例は 547 日以上継続投与さ れたが，これらの症例の多くは，投与期間中 BNPが 低值に維持されていることが明らかになった。

安全性については, 安全性解析対象の全 45 例で副 作用が認められた．主な副作用は頭痛が 34 例 (73.9\%), 潮紅が 31 例 (67.4\%)，ほてりが 26 例 (56.5\%) などの 血管拡張薬によくみられる副作用であった。

\section{9. 代謝}

肺高血圧症は難治性であり, BPS とボセンタン (34) あるいはシルデナフィル（35）との併用による有効性 の向上の報告もあることから, 単剤での効果が不十分 な場合, 他の経口肺高血圧症治療哓との併用による治 療が㧈こなわれる可能性がある。このため, BPSの

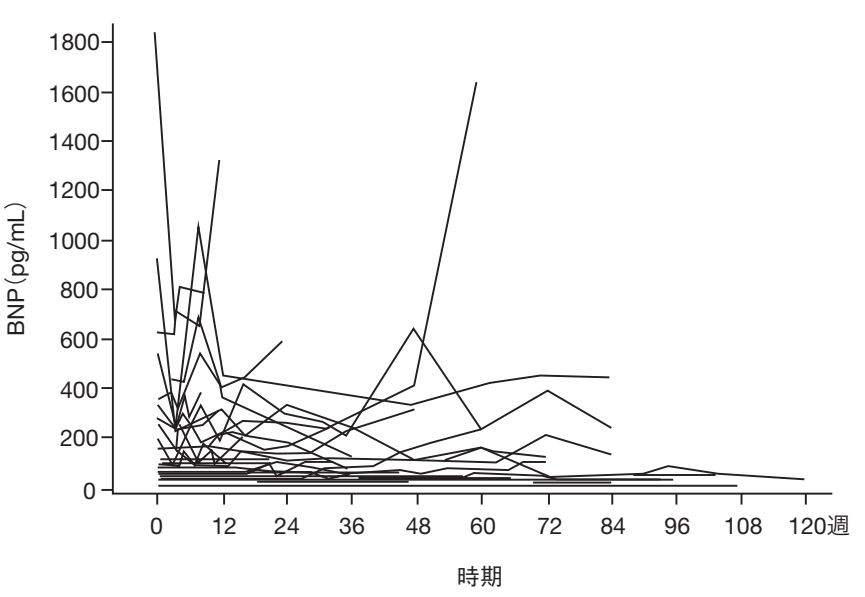

図 16 長期投与時における BNP 値の患者別推移

CYPに対する効果を検討した.

BPS の代謝に関与する CYP 分子種の同定を in vitro で行った結果, BPS は CYP2C8 で約 3\%とわずかに代 謝されたが，その他の分子種では代謝されなかった (36)。また，ヒト肝細胞において CYP 分子種を誘導 せず，ヒト肝ミクロソームを用いた検討において CYP 分子種の阻害作用を示さなかった (36). BPSの 代謝は主として $\beta$ 酸化, 15 位水酸基の酸化および 13 位二重結合の水素化, ならびにグルクロン酸抱合であ ることから (37)，ヒトに执いて BPS と CYPで代謝さ れる薬物との併用によって, 互いに血漿中濃度に影響 を及ぼす可能性は低いと推察された。

\section{0. 本剤の臨床における使用方法}

本剂の適応症は肺動脈性肺高血圧症であり，治験の 対象となった原発性肺高血圧症, 膠原病に伴う肺高血. 圧症以外に病態が類似する疾患も含まれる（図 2 ).

また本剤は, WHO 機能分類 I 度あるいは II 度といっ た軽度患者から投与できるという特徴を有する，膠原 病患者のうち強皮症や混合性結合組織病で肺高血圧症 を合併する比率は，それぞれ $11 \%, 16 \%$ と決して低く はない(38)。上述したように, 肺高血圧症は膠原病患 者の予後を規定する最も重要な合併症のひとつである ことから，心電図や心エコーなどで確実にフォローし 肺高血圧の早期発見に努める必要があるとされている (12). 本剤は経口鼡であり患者への負担が少ないこと, 副作用も頭痛, 潮紅, ほてりなどのプロスタサイクリ ン製剤や血管拡張薬に共通のもので, コントロール可 能であることが多い.このため本剤は特に, WHO 機 能分類 II 度の第 1 選択薬のひとつとして，あるいはIIIII度における併用薬としての使用が期待されている(39)。 


\section{1. おわりに}

近年プロスタサイクリン合成酵素のノックアウトマ ウス (40), プロスタサイクリン受容体ノックアウトマ ウス (41) において, 血栓形成の促進がみられたり, 心筋梗塞, 動脈硬化などの病態が増悪することが明ら かにされてきた，ヒトにおいても，プロスタサイクリ ン合成酵素の変異でプロスタサイクリンの産生が低く かったり (42), 受容体からのシグナル伝達に異常があ る遺伝子多型では (43), 高血圧, 循環器障害, 動脈硬 化などのリスクの高まることが報告されている。こう した例からも示されているように，生体内においてプ ロスタサイクリンは循環系を健全に保つ上で重要な役 割を担っており，その低下が循環器疾患のリスクを高 めることが, プロスタサイクリン発見後 30 年以上に なる今日になって，いっそう明確になってきている. 低下したプロスタサイクリンを無理なく補完できるケ アロード LA 錠, ベラサス LA 錠による治療は理にか なったものであり, 今回適応を取得した肺動脈性肺高 血圧症だけでなく, 今後広範な循環器疾患への展開が 期待できると考えている.

\section{文献}

1) Ohno K, et al. Adv Prostaglandin Thromboxane Leukot Res. 1987;15:279-281.

2) 大野清隆, 他 . Medchem News. 1993;3:37-41.

3) 西尾伸太郎, 他. 日薬理誌 . 2001;117:123-130.

4) 牛首文隆. 炎症 . 1998;18:393-404.

5) Moncada S, et al. Nature. 1976;263:663-665.

6) Niwano K, et al. Circ Res. 2003;93:523-530.
7) Miyahara Y, et al. Biochem Biophys Res Commun. 2006;349: 1242-1249.

8) Galie N, et al. Eur Heart. 2004;25:2243-2278.

9) 近藤啓文, 他 . Jpn J Clin Immun. 2002;25:215-226.

10) Koh ET, et al. Br J Rheumatol. 1996;35:989-993.

11) Rubin LJ. Circulation. 1982;66:334-348.

12) 日本循環器学会, 他. 肺高血圧症治療ガイドライン（2006 年 改訂版)

13) 福本義弘. Prog Med. 2004;24:314-316.

14）国枝武義,他. 臨床と研究 . 1997;74:2611-2629.

15) Galie N, et al. J Am Coll Cardiol. 2002;39:1496-1502.

16) Nagaya N, et al. J Am Coll Cardiol. 1999;34:1188-1192.

17）車谷元,他.血栓と循環 . 1999;7:185-196.

18) Chan S, et al. J Mol Cell Cardiol. 2008;44:14-30.

19) Rubin LJ. Chest. 1993;104:236-250.

20) Tamura M, et al. Prostaglandins Leukot Essent Fatty Acids. 2001; 64:197-202.

21) Nicolini FA, et al. Thromb Res. 1990;60:337-342.

22）安納重康,他。血栓と循環 . 2001;9:298-302.

23) Rubin LJ. Am J Cardiol. 1995;75:51A-54A.

24) Rubin LJ. Chest. 1993;104:236-250.

25）小野寺壮吉, 他 . 医薬のあゆみ. 1989;148:572-575.

26）寺尾岳.金沢大学十全医薬会雑誌. 1997;106:311-318.

27) Christman BW, et al. N Engl J Med. 1992;327:70-75.

28）大谷秀雄, 他. Therapeutic Res. 2001;22:2058-2060

29) Hadhazy P, et al. Prostaglandins. 1985;29:673-688.

30) Ikeda D, et al. J Cardiovasc Pharmacol. 2005;45:286-289.

31）ケアロード $\mathrm{LA}$ 錠 $60 \mu \mathrm{g}$, ベラサス ${ }^{\circledR} \mathrm{LA}$ 錠 $60 \mu \mathrm{g}$ 総合製品情 報概要

32）ケアロード ${ }^{\circledR} \mathrm{LA}$ 錠 $60 \mu \mathrm{g}$, ベラサス ${ }^{\oplus \mathrm{LA}}$ 錠 $60 \mu \mathrm{g}$ 申請資料 概要. 平成 19 年 10 月承認分.

33) Nagaya N, et al. Circulation. 2000;102:865-870.

34）小野文明,他. Therapeutic Res. 2007;28:1997-1999.

35) Itoh T, et al. Am J Respir Crit Care Med. 2004;169:34-38.

36) Fukazawa T, et al. YAKUGAKU ZASSHI. 2008;128:1459-1465.

37) 加藤隆一 , 他 . 臨床薬理 . 1989;20:515-517.

38）深谷修作, 他. Heart View. 2006;10:866-869.

39）田邊信宏, 日本臨床. 2008;66:2133-2138.

40) Yokoyama C, et al. Circulation. 2002;106:2397-2403.

41) Murata T, et al. Nature (Lond). 1997;388:678-682.

42) Nakayama T, et al. Curr Med Chem Cardiovasc Hematol Agents. 2005;3:157-164.

43) Arehart E, et al. Circ Res. 2008;102:986-993. 